\title{
ANAK YANG BERKONFLIK DENGAN HUKUM YANG MELAKUKAN PEMERKOSAAN TERHADAP ANAK
}

\author{
Astrid Ayu Pravitria \\ astridayupravitria@yahoo.com \\ Universitas Airlangga
}

\begin{abstract}
This journal titled "Child who had conflict with the law who done rape to child", which used a scientific method, Normative Juridical, by using statute approach, conseptual approach and case approach. The formulation of problem on this research is : (1) What is the characteristic of child who had conflict with the law who done rape to "child"?, (2) What is ratio decidendi of judge decision on child case who had conflict with the law who done rape to child, does it consider from the child aspect? (Based on child protection perspective) related to case decision number 206/Pid. Anak/2011/PN.Sby about rape which done by Achmad Suryo Raharjo Bin Abdullah (16 years old) to Tyas Wahyuningsih (15 years old) and case decision number 113/Pid.Anak/2012/PN.Sby about rape which done by Bayu Waskito Bin Aji (17 years old) to Sri Wahyuni (15 years and 6 months old). Using that approach producing result which, the first formulation of problem discussing about characteristic of child who had conflict with the law who done rape to child. From this discussion become clear about characteristic of child who had conflict with the law which is related to criminal rape offense with child as victim.
\end{abstract}

Keywords: Child Sentence Practice; rape; child who had conflict with the law.

\begin{abstract}
Abstrak
Jurnal ini berjudul “Anak Yang Berkonflik Dengan Hukum Yang Melakukan Pemerkosaan Terhadap Anak", yang dalam penulisannya digunakan metode penelitian yang bersifat yuridis normative, dengan menggunakan pendekatan undang-undang (statute approach), pendekatan konseptual (conseptual approach), dan pendekatan kasus (case approach). Rumusan masalah dalam penelitian ini adalah : (1) Apa karakteristik anak yang berkonflik dengan hukum yang melakukan pemerkosaan terhadap “Anak"?, (2) Apakah Ratio Decidendi Putusan Hakim dalam perkara anak yang berkonflik dengan hukum yang melakukan pemerkosaan terhadap anak, apakah sudah memperhatikan aspek perlindungan anak? (ditinjau dalam perspektif perlindungan anak) terkait dengan Putusan Perkara Nomor 206/Pid.Anak/2011/PN.Sby mengenai pemerkosaan yang dilakukan oleh Achmad Suryo Raharjo Bin Abdullah (16 Tahun) terhadap Tyas Wahyuningsih (15 Tahun) dan Putusan Perkara Nomor 113/Pid.Anak/2012/PN.Sby mengenai pemerkosaan yang dilakukan oleh Bayu Waskito Aji Bin Aji (17 Tahun) terhadap Sri Wahyuni (15 Tahun 6 Bulan). Dari pendekatan tersebut dihasilkan bahwa, rumusan masalah yang pertama membahas mengenai karakteristik anak yang berkonflik dengan hukum yang melakukan pemerkosaan terhadap anak. Dari pembahasan tersebut tersebut maka akan jelas terlihat mengenai karakteristik anak yang berkonflik dengan hukum dalam hal ini berkaitan dengan tindak pidana pemerkosaan yang korbannya anak.
\end{abstract}

Kata Kunci: Pemidanaan anak; pemerkosaan; anak yang berkonflik dengan hukum.

\section{Pendahuluan}

Anak merupakan generasi muda yang mana anak tersebut merupakan salah

satu sumber daya manusia yang berpotensi untuk meneruskan cita-cita bangsa. 
Anak dalam perkembangannya memerlukan pembinaan dan perlindungan yang menjamin pertumbuhan, perkembangan maupun kedewasaan baik secara fisik, mental, dan social secara utuh. Perkembangan anak sendiri merupakan sebuah proses dimana membutuhkan pengawasan maupun peran dari orang tua, keluarga maupun kerabat yang natinya dapat menjadikan salah satu pembentuk karakter yang baik untuk anak itu sendiri.

Peranan orang tua merupakan salah satu faktor yang paling dominan kepada seorang anak, keinginan orang tua untuk menjadikan anak sebagai seseorang yang baik, bertanggung jawab atas segala perbuatan yang dilakukannya menjadikan bagian terpenting dalam pembentukan karakter anak itu sendiri. Kebanyakan perilaku menyimpang pada anak juga disebabkan oleh kurangnya pengawasan dan perhatian orang tua, anak yang melakukan perbuatan menyimpang bahkan kebanyakannya dari perbuatan menyimpang tersebut digolongkan sebagai perbuatan yang melanggar hukum yang tidak jarang anak itu sendiri harus menjalani pidana atas pebuatannya.

Pentingnya peranan orang tua dalam pembentukan karakter seorang anak, menjauhkan anak itu sendiri dari label anak nakal, yang dalam hal ini pengertian anak nakal adalah anak yang menurut penjelasan Pasal 1 angka 1 Undang-Undang Nomor 3 Tahun 1997 tentang Pengadilan Anak, bahwa yang dimaksud Anak adalah orang yang dalam perkara "anak nakal”, kata anak nakal yang dimaksud didalam Pasal tersebut dijelaskan oleh aturan berikutnya yakni Pasal 1 angka 2 UndangUndang Nomor 3 tahun 1997 Tentang Pengadilan Anak, “Anak Nakal adalah:

1. Anak yang melakukan tindak pidana, atau

2. Anak yang melakukan perbuatan yang dinyatakan dilarang bagi anak, baik menurut peraturan perundang-undangan maupun menurut peraturan hukum lain yang hidup dan berlaku dalam masyarakat yang bersangkutan.”

Penjelasan tentang anak diatur dalam Pasal 1 angka 2 Undang-Undang Nomor 4 tahun 1979 Tentang Kesejahteraan Anak, secara garis besar yang disebut dengan anak adalah seorang yang berada pada usia dibawah 21 (dua puluh satu) tahun dan belum menikah. Hal ini bisa dilihat secara gamblang bahwa pengertian anak sangat 
berbeda dari setiap peraturan perundangan yang ada dan berlaku. Berdasarkan ketentuan diatas dapat disimpulkan bahwa yang dimaksud dengan anak adalah siapa saja yang belum mencapai usia 21 (dua puluh satu) tahun dan belum pernah kawin, beragam batas usia untuk seorang anak tidak menjadi penghalang bagi undangundang untuk mengatur dan membatasi ruang gerak bagi manusia sesuai dengan batas usia yang ada.

Pasal 1 angka 1 Undang-Undang Nomor 35 tahun 2014 tentang perubahan atas Undang-Undang No. 23 tahun 2002 tentang Perlindungan Anak, menjelaskan bahwa yang dimaksud anak adalah seseorang yang belum berusia 18 (delapan belas) tahun, termasuk anak yang masih dalam kandungan seorag ibu, pada Ayat 1 memuat batas antara belum dewasa dengan telah dewasa yaitu berumur 21 (dua puluh satu) tahun kecuali, jadi dapat disimpulkan bahwa yang dapat disebut dengan dewasa secara garis besar walaupun dia belum mencapai usia 21 tahun tetapi telah dan atau pernah melangsungkan suatu perkawinan, maka secara pasti dia akan disebut telah dewasa. pada Ayat 2 menjelaskan bahwa pembubaran perkawinan yang terjadi pada seseorang sebelum berusia 21 tahun, tidak mempunyai pengaruh terhadap kedewasaan.

Seorang anak memiliki hak dan kewajiban yang diatur dan dilindungi oleh undang-undang. Dimana seorang anak berhak untuk mendapatkan perlindungan dari lingkungan sekitar termasuk orangtua dan keluarga, sedangkan segala hak yang ada tersebut dilindungi oleh undang-undang, sehingga secara pasti tidak akan terabaikan segala hal yang menjadi seorang anak.

Pasal 2 Undang-Undang No. 4 tahun 1997 Tentang Kesejahteraan Anak menjelaskan:

1. Anak berhak atas kesejahteraan, perawatan, asuhan, dan bimbingan berdasarkan kasih sayang, baik dalam keluarganya maupun dalam asuhan khusus untuk tumbuh dan berkembang dengan wajar;

2. Anak berhak atas pelayanan untuk mengembangkan kemampuan dan kehidupan sosialnya, sesuai dengan kebudayaan dan kepribadian bangsa, untuk menjadi warga negara yang baik dan berguna;

3. Anak berhak atas pemeliharaan dan perlindungan, baik semasa kandungan maupun sesudah dilahirkan;

4. Anak berhak atas perlindungan terhadap lingkungan hidup yang dapat 
membahayakan atau menghambat pertumbuhan dan perkembangan dengan wajar.

Seorang anak memiliki kebutuhan dasar yang wajib untuk dipenuhi sehingga proses tumbuh kembangnya dapat terpenuhi. Hubungan baik antar keluarga adalah hal yang paling wajib untuk dipenuhi dikarenakan hal tersebut menjadi dasar bagi tumbuh kembang anak. ${ }^{1}$ Huttman menjelaskan tentang berbagai macam kebutuhan seorang anak, yaitu:

1. Kasih-sayang orangtua;

2. Stabilitas emosional;

3. Pengertian dan perhatian;

4. Pertumbuhan kepribadian;

5. Dorongan kreatif;

6. Pembinaan kemampuan intelektual dan keterampilan dasar;

7. Pemeliharaan kesehatan;

8. Pemenuhan kebutuhan makanan, pakaian, tempat tinggal yang sehat dan memadai;

9. Aktivitas rekreasional yang konstruktif dan positif;

10. Pemeliharaan, perawatan dan perlindungan.

Peranan orangtua menjadi dominan, hal ini dikarenakan orangtua merupakan awal seorang anak belajar tentang sebuah kehidan, dan orangtua merupakan ujung tombak dalam sebuah kehidupan. Orang tua lah yang mendidik seorang dari kecil hingga dewasa sehingga dapat dilihat kebutuhan anak terpenuhi atau tidak oleh orangtuanya dari sikap anak tersebut. Suatu kegagalan dalam proses tumbuh kembang seorang anak menjadikan anak menjadi susah diatur atau dapat disebut dengan cap masyarakat sebagai anak nakal. Hal ini berdampak negatif pada seorang anak yang sudah terdoktrin didalam dirinya bahwa telah menjadi seorang anak nakal, dan hal tersebut menjadi gangguan tersendiri dalam perkembangan fisik, mental dan kehidupan seorang anak.

Berdasarkan Pasal 1 angka 7 Undang-Undang Nomor 11 tahun 2012 tentang Sistem Pengadilan Pidana Anak menjelaskan tentang diversi, yaitu pengalihan penyelesaian perkara seorang anak dari proses peradilan pidana ke proses di luar peradilan pidana. Sedangkan Keadilan Restorative (Restorative Justice)

\footnotetext{
1 Huraerah/Repositary.usu.ac.id
} 
adalah penyelesaian perkara tindak pidana dengan melibatkan pelaku, korban, keluarga pelaku/ korban, dan pihak lain yang terkait untuk bersama-sama mencari penyelesaian yang adil dengan memilih cara pemulihan korban sehingga dapat normal kembali, dan tidak menitik beratkan pada sebuah pembalasan.

Dengan adanya diversi membuat hak anak menjadi terjamin, dengan demikian menghindarkan anak dari cap sebagai "anak nakal”. Hal ini dikarenakan suatu tindak pidana yang melibatkan anak sebagai pelaku bisa diproses tanpa perlu melalui prosedur hukum. Pasal 6 Undang-Undang Nomor 11 tahun 2012 tentang Sistem Pengadilan Pidana Anak menjelaskan tentang tujuan diversi, yaitu:

1. Mencapai perdamaian antara korban dan Anak;

2. Menyelesaikan perkara Anak di luar proses peradilan;

3. Menghindarkan Anak dari perampasan kemerdekaan;

4. Mendorong masyarakat untuk berpartisipasi; dan

5. Menanamkan rasa tanggung jawab kepada Anak.

Upaya hukum secara diversi menjadi kabur secara pengertian dikarenakan bahwa tidak semua tindak pidana yang dilakukan oleh seorang anak dapat diupayakan secara diversi, hal ini diatur dalam Pasal 7 ayat (2) Undang-Undang Nomor 11 tahun 2012 tentang Sistem Pengadilan Pidana Anak, yaitu :

1. Tindak pidana yang diancam dengan pidana penjara di bawah 7 (tujuh) tahun; dan

2. Bukan merupakan pengulangan tindak pidana.

Banyaknya putusan pengadilan anak yang cenderung menjatuhkan pidana penjara terhadap anak nakal, pada dasarnya tidak sesuai dengan pengertian dan penjelasan dari pemidanaan dalam hukum pidana anak. Penjatuhan pidana secara tidak tepat dapat mengabaikan pengaturan perlindungan, karena pemidanaan anak seharusnya adalah jalan keluar terakhir (ultimum remedium / the last resort principle) dan dijatuhkannya hanya untuk waktu yang singkat. Istilah "ultimum remidium" menjelaskan bahwa sanksi pidana digunakan saat sanksi-sanksi yang lainnya sudah tidak dapat diterapkan. Maka dapat disimpulkan bahwa sanksi pidana merupakan jalan terakhir yang nantinya akan ditempuh setelah sanksi perdata dan 
sanksi administratif. ${ }^{2}$

Telah diundangkan dan berlaku Undang-Undang Nomor 11 tahun 2012 tentang Sistem Peradilan Pidana Anak, dimana dalam undang-undang ini pemidanaan terhadap Anak Nakal berlandaskan pada Keadilan Restoratif/restorative justice ini lebih menitik-beratkan pada kondisi sebuah keadilan dan keseimbangan bagi pelaku tindak pidana dan korban. Mekanisme tata acara dalam peradilan pidana akan fokus pada pemidanaan, dan akan diganti menjadi proses dialog dan mediasi agar tercipta suatu kesepakatan akan penyelesaian perkara pidana sehingga nantinya akan menjadi adil dan seimbang bagi pihak korban dan pelaku. Yang akan sejalan dengan Prisip Umum Perlindungan Anak yang menjadi dasar terbentuknya suatu perlindungan hukum bagi anak. Pendekatan Keadilan Restoratif dalam Sistem Peradilan Pidana Anak, yaitu:

1. Penyidikan dan penuntutan pidana Anak yang dilaksanakan sesuai dengan ketentuan peraturan perundang-undangan, kecuali ditentukan lain dalam Undang-Undang No. 11 tahun 2012 tentang Sistem Peradilan Pidana Anak;

2. Persidangan Anak yang dilakukan oleh pengadilan di lingkungan peradilan umum, dan;

3. Pembinaan, pembimbingan, pengawasan, dan/atau pendampingan selama proses pelaksanaan pidana atau tindakan dan setelah menjalani pidana atau tindakan.

Hasil kesepakatan dituangkan dalam bentuk kesepakatan Diversi yang disampaikan oleh pejabat yang bertanggung jawab di setiap tingkat pemeriksaan di pengadilan negeri sesuai dengan daerah hukumnya dalam waktu paling lama 3 (tiga) hari sejak kesepakatan dicapai. hal tersebut menjadi sebuah penetapan yang dilakukan dalam waktu paling lama 3 (tiga) hari terhitung sejak diterimanya kesepakatan Diversi. ${ }^{3}$

Dilihat dari berbagai posisi yang wajib melindungi Hak Anak adalah negara, dan orang tua secara khusus. Hal ini mengingat adanya kuwajiban orang tua untuk memenuhi hak seorang anak untuk hidup secara layak baik sebelum maupun setelah

\footnotetext{
Hadi Supena, Kriminalisasi Anak (PT Gramedia Pustaka Utama 2010).

3 www.fianhar.com/2014/10/Kedudukan-anak-dalam-kejahatan.html
} 
dilahirkan. ${ }^{4}$ Menurut Undang-Undang No. 35 tahun 2014 perubahan atas UndangUndang No. 23 tahun 2002 tentang Perlindungan Anak, hak anak adalah bagian dari hak asasi manusia yang wajib dijamin, dilindungi dan dipenuhi oleh orangtua, masyarakat, pemerintah dan negara. Penjelasan secara pasti akan lebih banyak dijelaskan bahwa hak anak termasuk dalam hak asasi manusia, sehingga dapat dipastikan bahwa anak adalah bagian masyarakat yang harus diharhai pendapat maupun keberadaannya dalam kehidupan masyarakat.

Definisi anak dan pelanggaran hukum menurut Peraturan Minimum Standar Perserikatan Bangsa-Bangsa mengenai Administrasi Peradilan Bagi Remaja (Boijing Rules), adalah :

1. Seorang anak adalah seorang anak atau orang muda yang menurut sistem hukum masing-masing dapat diperlakukan atas suatu pelanggaran hukum dengan cara yang berbeda dari perlakuan terhadap orang dewasa;

2. Kedua, suatu pelanggaran hukum adalah perilaku apapun (tindakan atau kelalaian) yang dapat dihukum oleh hukum menurut sistem-sitem hukum masing-masing;

3. Ketiga, seorang pelanggar hukum berusia remaja adalah seorang anak atau orang muda yang diduga telah melakukan atau yang telah ditemukan telah melakukan suatu pelanggaran hukum.

Pasal 1 ayat 2 Undang-undang No. 3 Tahun 1997 tentang Peradilan Anak, menyebutkan anak-anak nakal adalah:

1) Anak yang melakukan tindak pidana ; atau

2) Anak yang melakukan perbuatan yang dinyatakan terlarang bagi anak, baik menurut peraturan perundang-undangan maupun menurut peraturan hukum lain.

Di Indonesia, terdapat batasan usia pada anak yang dapat diajukan ke sidang anak dalam rentan usia 8 (delapan) tahun hingga 18 (delapan belas) tahun. Tetapi bagi anak yang melakukan tindak pidana pada usia 8 (delapan) tahun hingga 12

\footnotetext{
4 Mukadimah Konvensi Hak-Hak Anak.
} 
(dua belas) tahun hanya dapat dikenakan tindakan. Dengan demikian, batas usia untuk anak yang melakukan tindak pidana dan dapat dipertanggungjawabkan dalam hukum pidana dan dijatuhi pidana adalah usia 12 (dua belas) tahun hingga 18 (delapan belas) tahun.

Anak yang belum mencapai umur 8 (delapan) tahun dan telah melakukan tindak pidana, maka menurut pasal 5 Undang-undang pengadilan anak Nomor 3 Tahun 1997, maka dapat dilakukan pemeriksaan oleh penyidik. Hasil yang nantinya akan keluar akan menentukan apakah anak tersebut akan dikembalikan kelingkungannya ataukan akan dibina oleh negara. Dengan maksud bahwa apabila dikembalikan kelingkungannya maka anak tersebut dapat bergaul dan belajar tentang kesalahannya dengan bimbingan orangtua dan mendapat dukungan dari lingkungannya.Support keluarga dan lingkungan sangat membantu proses pemulihan kondisi baik bagi korban anak maupun pelaku anak. Lebih bijaksana lagi apabila dalam kondisi seorang pelaku tindak pidana adalah seorang anak, maka dengan dikembalikan kepada orangtua maka proses belajar yang seharusnya didapat akan terpenuhi tentang adanya kasih sayang, perhatian dan segala hal yang menyangkut si anak, hal ini berbanding terbalik apabila seorang pelaku tindak pidana adalah anak yang dijatuhi hukuman pidana. Hal ini dikarenakan dicabutnya haknya sebagai anak untuk merasakan perhatian dan perlindungan dari keluarga terutama orangtua.

\section{Tindak Pidana Pemerkosaan}

Pemerkosaan adalah suatu tindakan kriminal berwatak seksual yang terjadi ketika seorang manusia (atau lebih) memaksa manusia lain untuk melakukan hubungan seksual dalam bentuk penetrasi vagina atau anus dengan penis, anggota tubuh lainnya seperti tangan, atau dengan benda-benda tertentu secara paksa baik dengan kekerasan atau ancaman kekerasan.

\section{Perlindungan Anak}

Penanganan terhadap anak yang berkonflik dengan hukum adalah merupakan tanggung jawab dan kewajiban bersama antara masyarakat dan pemerintah, seperti 
yang dijelaskan dalam Pasal 64 Undang-Undang Nomor 35 tahun 2014 perubahan atas Undang-Undang Nomor 23 tahun 2002 tentang Perlindungan Anak, yaitu:

1. Perlindungan khusus bagi anak yang berhadapan dengan hukum, meliputi anak berkonflik dan anak korban tindak pidana adalah merupakan kewajiban dan tanggung jawab pemerintah dan masyarakat.

2. Perlindungan khusus bagi anak yang berhadapan dengan hukum dilaksanakan melalui; perlakuan atas anak secara manusiawi sesuai dengan martabat dan hakhak anak, penyediaan petugas pendamping khusus anak sejak dini, penyediaan sarana dan prasarana khusus, penjatuhan sanksi yang tepat untuk kepentingan terbaik anak, pemantauan dan pencatatan secara kontinyu terhadap perkembangan anak, pemberian jaminan untuk berhubungan dengan orang tua atau keliarga, perlindungan dari pemberitaan oleh media dan menghindar dari labelisasi.

3. Perlindungan khusus bagi anak yang menjadi korban tindak pidana dilaksanakan melalui: upaya rehabilitasi baik dalam lembaga maupun diluar lembaga, upaya perlindungan dari pemberitaan identitas melalui media massa dan untuk menghindari labelisasi, pemberian jaminan keselamatan bagi sanksi korban ahli baik fisik mental maupun sosial, pemberian aksesibilitas untuk mendapatkan informasi mengenai perkembangan perkara.

\section{Undang-Undang Yang Mengatur Mengenai Perlindungan Anak}

Ketentuan Undang-Undang Nomor 23 Tahun 2002 tentang Perlindungan Anak sebagaimana telah diubah dengan Undang-Undang Nomor 35 Tahun 2014 (“UU Perlindungan Anak") yang berkaitan dengan tindak pidana kesusilaan yaitu antara lain Pasal 76 D (persetubuhan dengan anak) dan Pasal 76 E (pencabulan anak), sebagai berikut:

1) Pasal 76 D Undang-Undang Nomor 35 Tahun 2014 tentang Perlindungan Anak jo Undang-Undang Nomor 23 Tahun 2002 tentang Perlindungan Anak, menyebutkan bahwa setiap orang dilarang melakukan Kekerasan atau ancaman Kekerasan memaksa Anak melakukan persetubuhan dengannya atau dengan orang lain. 
2) Pasal 76 E Undang-Undang Nomor 35 Tahun 2014 tentang Perlindungan Anak jo Undang-Undang Nomor 23 Tahun 2002 tentang Perlindungan Anak, menyebutkan tentang setiap orang dilarang melakukan Kekerasan atau ancaman Kekerasan, memaksa, melakukan tipu muslihat, melakukan serangkaian kebohongan, atau membujuk Anak untuk melakukan atau membiarkan dilakukan perbuatan cabul.

\section{Kausalitas Penanganan Perkara Anak Pelaku Pemerkosaan Terhadap "Anak"}

Sistem Hukum Pidana Indonesia mengalami perubahan, didalam pengaturan mengenai hukum pidana dalam perspektif dan pencapaian keadilan kepada perbaikan maupun pemulihan keadaan setelah peristiwa dan proses peradilan pidana yang biasanya dikenal dengan keadilan restoratif (restoratif justice) yang berbeda dengan keadilan retributif (menekankan keadilan pada pembalasan) dan keadilan restitutif (menekankan keadilan pada ganti rugi). Ditinjau dari perkembangan ilmu hukum pidana itu sendiri telah memperkenalkan dan mengembangkan apa yang disebut pendekatan hubungan Pelaku-Korban atau "Doer-Victims" Relationship. Suatu pendekatan baru yang telah menggantikan pendekatan perbuatan atau pelaku atau "daad-dader straftecht". 5

Terdapat 3 (tiga) aspek pendekatan untuk membangun suatu sistem hukum dalam rangka modernisasi dan pembaharuan hukum, yaitu :

1. segi struktur (structure);

2. substansi (substance) serta,

3. budaya (legal culture) yang kesemuanya layak berjalan secara integral, simultan dan paralel.

Anak merupakan elemen terpenting bagi suatu negara dimana anak dapat berkembang dan menjadikan suatu negara baik apabila didukung oleh lingkungan dan pendidikan baik formal maupun tidak formal secara utuh. Anak merupakan

\footnotetext{
$5 \quad$ https://www.mahkamahagung.go.id/id/artikel/2613/keadilan-restoratif-sebagai-tujuanpelaksanaan-diversi-pada-sistem-peradilan-pidana-anak
} 
harapan suatu bangsa dimasa yang akan datang dan akan melanjutkan kepemimpinan suatu bangsa. Kewajiban seorang anak untuk memperoleh pendidikan yang layak agar tumbuh menjadi sosok yang berguna bagi bangsa dan negara dikedepannya. Hal ini sesuai dengan ketentuan Konvensi Hak Anak (Convention on the Rights of the Child) yang diratifikasi oleh pemerintah Indonesia melalui;

1. Undang - Undang Nomor 4 Tahun 1979 tentang Kesejahteraan Anak;

2. Keputusan Presiden Nomor 36 Tahun 1990;

3. Undang-Undang Nomor 11 Tahun 2012 tentang Sistem Peradilan Pidana Anak; 4. Undang - Undang Nomor 35 Tahun 2014 tentang Perlindungan Anak.

dimana kesemuanya mengemukakan tentang adanya prinsip-prinsip umum tentang perlindungan anak, yaitu non diskriminasi, kepentingan terbaik bagi anak, kelangsungan hidup dan tumbuh kembang dan menghargai partisipasi anak.

Tumbuh kembang seorang anak menjadi tanggung jawab orang tua dan dengan dukungan lingkungan. Dimana seorang anak menjadi baik apabila terdapat dalam lingkungan yang baik juga. Hal terbalik ditemui pada lingkungan yang tidak baik. Dimana pada lingkungan yang kurang baik maka ada anak yang kehilangan haknya dalam berpartisipasi di lingkungannya. Kehilangan hak sebagai seorang anak akan membuat anak tersebut melampiaskan rasa emosionalnya kepada diri dan lingkungannya. Hal inilah yang nantinya menjadi salah persepsi tentang baik dan benar. Penentuan baik dan benar hanya dapat dibedakan dan diketahui oleh orang dewasa. Seorang anak hanya dapat mengikuti apa yang dilihat, didengar dan yang sudah menjadi kebiasaan dari orang yang ada disekitarnya. Hal ini menimbang dari kebelum matangan seorang anak tersebt dalam membedakan baik dan buruknya. Seorang anak yang belum memiliki kematangan dalam berpikir dipaksa agar menentukan sikapnya untuk kemudian hari, dimana tingkah laku anak dapat menimbulkan suatu kerugian bagi diri dan lingkungannya. Dampak pasti dari buruknya lingkungan adalah pembentukan karakter, ciri, dan sifat kekhususan bagi seorang anak. Bimbingan orangtualah menjadikan anak terhindar dari prekat anak nakal, bukan hukuman pidana yang nantinya akan mengancam dan membatasi ruang gerak dan pikiran anak. Sedangkan hak seorang anak adalah untuk mendapatkan 
perlindungan dari orangtua, lingkungan, dan negara.

\section{Sanksi Anak Pelaku Pemerkosaan Terhadap “Anak"}

Penerapan sanksi pidana yang menjadi penerapan sanksi terakhir setelah sanksi perdata dan sanksi administrasi. Merupakan jalan terakhir yang harus diupayakan demi adanya penegakan keadilan bagi korban. Dimana penderitaan korban akan berkurang dengan adanya sanksi pidana yang diterapkan bagi pelaku tindak pidana. Pelaku kejahatan seksual atau kejahatan pemerkosaan harus mendapatkan sanksi hukuman yang berat untuk mengembalikan rasa keadilan bagi korban, bahkan diperlukan adanya hukuman tambahan bagi pelaku. Perasaan tidak adil yang dimiliki korban tindak pidana pemerkosaan, wajib diutamakan. Hal ini berkaitan dengan adanya pengembalian hak anak untuk hidup normal dan berpartisipasi penuh dalam masyarakat. Tindak pidana pemerkosaan merupakan salah satu tindak kejahatan yang sangat keji dan tidak berperikemanusiaan. Pengertian perkosaan sendiri adalah seseorang pria yang memaksa pada seorang wanita bukan isterinya untuk melakukan persetubuhan dengannya dengan ancaman kekerasan, yang mana diharuskan kemaluan pria telah masuk ke dalam lubang kemaluan seorang wanita yang kemudian mengeluarkan air mani. Tindak kejahatan pemerkosaan tidak hanya melanggar norma kesusilaan dan norma agama saja, tetapi juga telah melanggar hak asasi manusia yang melekat pada diri korban, apalagi yang menjadi korban pemerkosaan adalah anak yang masih di bawah umur.

Pelaku pemerkosaan harus mendapatkan hukuman yang berat, agar mampu memberikan efek jera bagi pelaku. Perlu adanya peraturan hukum mengatur mengenai sanksi hukuman yang berat terhadap pelaku kejahatan pemerkosaan, selain itu juga diperlukan ketegasan dari aparat penegak hukum dalam memberikan sanksi hukuman tersebut. Tindak kejahatan pemerkosaan secara umum telah diatur dalam Pasal 287 ayat (1) Kitab Undang Undang Hukum Pidana (KUHP) yang berbunyi;

(1) Barang siapa bersetubuh dengan seorang wanita di luar perkawinan, padahal diketahuinya atau sepatutnya harus diduganya bahwa umumya belum lima belas tahun, atau kalau umurnya tidak jelas, bawa belum waktunya untuk 
dikawin, diancam dengan pidana penjara paling lama sembilan tahun.

Tindak kejahatan Pemerkosaan dengan korban anak yang masih di bawah umur dengan korban orang dewasa tentunya akan berbeda, baik dari penanganan korbannya maupun penegakan hukumnya. Korban pemerkosaan terhadap anak di bawah umur tentunya masih memiliki masa depan yang panjang yang seharusnya mampu dijaga dan dilindungi, karena merupakan generasi penerus kehidupan bangsa. Sanksi hukuman terhadap pelaku pemerkosaan terhadap anak yang masih di bawah umur telah diatur sendiri di dalam pasal 81 ayat (1) dan (2) UndangUndang Perlindungan Anak Nomor 35 Tahun 2014 tentang Perubahan UndangUndang Perlindungan Anak Nomor 23 Tahun 2002 yang berbunyi:

Pasal 81

(1) Setiap orang yang dengan sengaja melakukan kekerasan atau ancaman kekerasan memaksa anak melakukan persetubuhan dengannya atau dengan orang lain, dipidana dengan pidana penjara paling lama 15 (lima belas) tahun dan paling singkat 5 (lima) tahun dan denda paling banyak Rp 5.000.000.000,00 (lima miliar rupiah).

(2) Ketentuan pidana sebagaimana dimaksud dalam ayat (1) berlaku pula bagi setiap orang yang dengan sengaja melakukan tipu muslihat, serangkaian kebohongan, atau membujuk anak melakukan persetubuhan dengannya atau dengan orang lain.

Pemerintah dalam menghadapi peningkatnya jumlah kejahatan pemerkosaan terhadap anak adalah dengan mengeluarkan Peraturan Pemerintah Pengganti Undang-Undang (PERPPU) Nomor 1 Tahun 2016 tentang Perubahan ke-2 atas Undang-Undang Nomor 23 Tahun 2002 tentang Perlindungan Anak. Perpu tersebut mengatur yang salah satunya mengenai hukuman kebiri kimia bagi kejahatan seksual.

\section{Pembahasan Kasus Putusan No 206/Pid.Anak/2011/PN.SBY}

Pemerkosaan merupakan perbuatan yang melawan hukum, yang dalam hal ini dalam Kasus tindak pidana pemerkosaan, Achmad Suryo Raharjo telah terbukti secara sah dan meyakinkan bahwasannya dirinya memang bersalah melakukan tindak pidana sebagaimana melanggar Pasal 81 ayat 2 Undang-undang Nomor 23 tahun 2002 tentang Perlindungan Anak. Akan tetapi ada beberapa pertimbangan 
lain yang dalam hal ini, jika mengingat bahwa Achamad Suryo Raharjo melakukan tindak pidana pemerkosaan tersebut, saat dirinya berusia 16 (enam belas) tahun, dan Tyas Wahyuningsih juga berusia 15 (lima belas) tahun, jadi dalam hal ini keduaduanya masih termasuk katagori Anak, dikarenakan belum berumur 18 (delapan belas) tahun, sehingga Terdakwa juga berhak mendapat perlindungan khusus. Yang dimaksud dengan Negara memberikan perlindungan khusus terhadap Anak dalam Undang-undang Nomor 23 tahun 2002 tentang Perlindungan Anak, yang diperuntukkan bagi Anak yang Berhadapan dengan Hukum $(\mathrm{ABH})$ baik anak yang berkonflik dengan hukum maupun anak sebagai saksi korban, sehingga Undangundang Perlindungan Anak bukan hanya memberikan perlindungan kepada anak sebagai korban saja, tetapi juga memberikan perlindungan kepada Anak sebagai pelaku tindak pidana, sehingga diberlakukan Pengadilan Khusus bagi Anak yaitu Pengadilan Anak sebagaimana diatur dalam Undang-Undang Nomor 3 tahun 1997 tentang Pengadilan Anak.

Selain itu, adapun pertimbangan lain berdasarkan Undang-undang Perlindungan Anak yaitu pada Pasal 1 ayat 1 Undang-undang Nomor 3 tahun 1997 tentang Pengadilan Anak menyatakan bahwa : "Anak adalah orang yang dalam perkara anak nakal telah mencapai umur 8 (delapan) tahun tetapi belum mencapai umur 18 (delapan belas) tahun dan belum pernah kawin“, dan terhadap Achmad Suryo Raharjo yang oleh karena pada saat melakukan tindak pidana umur belum mencapai 18 (delapan belas) tahun, maka Achmad Suryo Raharjo berhak mendapatkan perlindungan hukum sebagaimana dimaksud oleh Undang-undang Perlindungan Anak dan dengan memberikan pertimbangan atas kebaikan masa depan Achmad Suryo Raharjo agar hidupnya lebih sejahtera sebagaimana tertuang pada Pasal 64 ayat 2 huruf d Undang-undang Nomor 23 tahun 2002 tentang Perlindungan Anak.

Dengan telah terbukti Achmad Suryo Raharjo yang secara sah dan telah meyakinkan bahwasannya dirinya memang benar bersalah melakukan tindak pidana, maka Achmad Suryo Raharjo harus dijatuhi pidana sesuai dengan tingkat kesalahannya, akan tetapi dalam menjatuhkan "pidana" atau "tindakan" kepada 
Achmad Suryo Raharjo yang dalam hal ini harus benar-benar dapat memberikan rasa keadilan kepada keluarga kedua belah pihak dan masyarakat, dengan harapan dapat memberikan pendidikan serta manfaat bagi kehidupan dan masa depannya. Sedangkan mengenai pemidanaannya, semua bergantung pada pertimbangan Hakim yang dalam hal ini selama tidak melenceng pada perundang-undangan yang berlaku, serta berdasarkan putusan yang nantinya dijatuhkan oleh Hakim yang bersangkutan diharapkan dapat memberikan contoh dan pembelajaran pada masyarakat agar tidak melakukan hal tersebut. Dalam hal lain yang berhubungan dengan perbuatan Achmad Suryo Raharjo yang dengan sengaja mengakibatkan Tyas Wahyuningsih mengandung janin 14 (empat belas) minggu. Akan tetapi jika dapat dilihat dari sudut Achmad Suryo Raharjo selaku Terdakwa dalam hal ini maka pertimbangan yang dapat digunakan adalah usia Achmad Suryo Raharjo yang tergolong masih muda dan, diharapkan masih bisa menjadi manusia yang berguna dikemudian hari. Pertimbangan lain terdapat pada Pasal 80 ayat 3 Undang-undang Nomor 23 Tahun 2002 tentang Perlindungan Anak jo Undang-undang Nomor 3 Tahun 1997 tentang Pengadilan Anak jo Undang-undang Nomor 8 tahun 1981 tentang Hukum Acara Pidana.

\section{Pembahasan Kasus Putusan No 113/Pid.Anak/2012/PN.SBY}

Pemerkosaan merupakan perbuatan yang melawan hukum, yang dalam hal ini dalam Kasus Tindak Pidana Pemerkosaan, Bayu Waskito Aji telah terbukti secara sah dan meyakinkan bahwa dirinya memang bersalah melakukan tindak pidana sebagaimana melanggar Pasal 81 Ayat 1 Undang-Undang Nomor 23 Tahun 2002 tentang Perlindungan Anak. Akan tetapi ada beberapa pertimbangan lain yang dalam hal ini, jika mengingat bahwa Bayu Waskito Aji melakukan tindak pidana Tindak Pidana Pemerkosaan, saat dirinya berusia 17 (tujuh belas) tahun, dan Sri Wahjuni juga berusia 15 (lima belas) tahun 6 (enam) bulan, sehingga keduanya masih termasuk katagori Anak, hal ini dikarenakan keduanya belum berumur 18 (delapan belas) tahun, sehingga terdakwa juga berhak mendapat perlindungan khusus. Yang dimaksud dengan Negara memberikan perlindungan khusus terhadap 
Anak dalam Undang-Undang Nomor 23 Tahun 2002 tentang Perlindungan Anak, diperuntukkan bagi Anak yang Berhadapan dengan Hukum (ABH) baik Anak yang berkonflik dengan hukum maupun Anak sebagai saksi korban, sehingga UndangUndang Perlindungan Anak bukan hanya memberikan perlindungan kepada Anak sebagai korban saja, tetapi juga memberikan perlindungan kepada Anak sebagai pelaku tindak pidana, sehingga diberlakukan Pengadilan Khusus bagi Anak yaitu Pengadilan Anak sebagaimana diatur dalam Undang-Undang Nomor 3 tahun 1997 tentang Pengadilan Anak.

Selain itu, adapun pertimbangan lain yangmana berdasarkan Undang-undang Perlindungan Anak, Pasal 1 Ayat 1 Undang-Undang Nomor 3 Tahun 1997 tentang Pengadilan Anak menyatakan, bahwa "Anak adalah orang yang dalam perkara anak nakal telah mencapai umur 8 (delapan) tahun tetapi belum mencapai umur 18 (delapan belas) tahun dan belum pernah kawin“, dan terhadap Bayu Waskito Aji yang oleh karena pada saat melakukan tindak pidana umur belum mencapai 18 (delapan belas) tahun, maka Bayu Waskito Aji berhak mendapatkan perlindungan hukum sebagaimana dimaksud oleh Undang-undang Perlindungan Anak dan dengan memberikan pertimbangan atas kebaikan masa depan Bayu Waskito Aji agar hidupnya lebih sejahtera sebagaimana tertuang pada Pasal 64 Ayat 2 huruf d Undang-Undang Perlindungan Anak.

Dengan telah terbukti Bayu Waskito Aji yang secara sah dan telah meyakinkan bahwa dirinya memang benar bersalah melakukan tindak pidana, maka Bayu Waskito Aji harus dijatuhi pidana sesuai dengan tingkat kesalahannya, akan tetapi dalam menjatuhkan "pidana" atau "tindakan" kepada Achmad Suryo Raharjo yang dalam hal ini harus benar-benar dapat memberikan rasa keadilan kepada keluarga kedua belah pihak dan masyarakat, dengan harapan dapat memberikan pendidikan serta manfaat bagi kehidupan dan masa depannya. Sedangkan mengenai pemidanaannya, semua bergantung pada pertimbangan Hakim yang dalam hal ini selama tidak melenceng pada perundang-undangan yang berlaku, serta berdasarkan putusan yang nantinya dijatuhkan oleh Hakim yang bersangkutan diharapkan dapat memberikan contoh dan pembelajaran pada 
masyarakat agar tidak melakukan hal tersebut. Dalam hal lain yang berhubungan dengan perbuatan Bayu Waskito Aji yang dengan sengaja mengakibatkan Sri Wahjuni merasa malu dan kehilangan harga dirinya. Akan tetapi jika dapat dilihat dari sudut Bayu Waskito Aji selaku Terdakwa dalam hal ini maka pertimbangan yang dapat digunakan adalah usia Bayu Waskito Aji yang tergolong masih muda dan, diharapkan masih bisa menjadi manusia yang berguna dikemudian hari. Pertimbangan lain terdapat pada Pasal 80 ayat 3 Undang-Undang Nomor 23 Tahun 2002 tentang Perlindungan Anak jo Undang-Undang Nomor 3 Tahun 1997 tentang Pengadilan Anak jo Undang-Undang Nomor 8 Tahun 1981 tentang Hukum Acara Pidana. Jika dilihat dari sudut pandang anak maka hukuman yang diterapkan bagi korban dan pelaku tindak pidana pemerkosaan adalah sesuai porsinya.

\section{Kesimpulan}

Anak merupak generasi penerus bangsa yang harus dilindungi hak dan kewajibannya. Dimana setiap anak memperoleh hak yang sama dalam hal partisipasi dalam masyarakat. Hal ini jelas diatu dalam Undang-Undang. Bagi anak yang memiliki keterlibatan dalam hukum, baik sebagai pelaku, saksi maupun korban memiliki hak yang sama. Negara memfasilitasi setiap anak agar dapat berpartisapi sebagai penerus bangsa. Hal ini dijelaskan lebih lanjut dalam fasilitas pemerintah yang memberikan pendidikan bagi anak, baik yang dilakukan didalam keluarga ataupun yang dilakukan secara formal. Karakteristik anak sebagai pelaku tindak pidana, dapat dikatagorikan sebagai anak yang berhadapan dengan hukum $(\mathrm{ABH})$, dalam hal ini pengertian anak nakal itu sendiri diatur dalam Pasal 1 angka 1 Undang-Undang Nomor 3 Tahun 1997 Tentang Peradilan Anak, penjelasan lebih lanjut terdapat pada angka 2, dalam pasal 1 angka 2 Undang-Undang Nomor 3 Tahun 1997 tentang Peradilan Anak, menyebutkan : “anak nakal adalah (1) Anak yang melakukan tindak pidana, atau (2) anak yang melakukan perbuatan yang dinyatakan dilarang bagi anak, baik menurut peraturan perundang-undangan maupun menurut peraturan hukum yang lain yang hidup dan berlaku dimasyarakat". Perlindungan maupun proses pembinaan terhadap anak yang dihadapkan pada 
permasalahan maupun tantangan di masyarakat yang terkadang dapat dijumpai penyimpangan perilaku di kalangan anak dan perbuatan yang melanggar hukum tanpa memandang status sosial dan ekonomi di samping itu terdapat pula anak yang karena salah satu hal, tidak mempunyai kesempatan untuk berkembang baik secara mental, fisik maupun sosial, karena keadaan tersebut sering kali terjadi maupun tidak, anak melakukan tindakan atau perilaku yang dapat merugikan dirinya sendiri atau masyarakat dalam menangani berbagai perbuatan dan tingkah laku anak yang melanggar hukum, perlu dipertimbangkan keadaan anak dalam segala kharakter, ciri dan sifat yang khas. Dalam hal ini pertanggungjawaban dapat dilakukan beberapa penyelesaian yang berdasarkan keadilan restorative dalam penyelesaian perkara tindak pidana yang dilakukan oleh anak tersebut maka diselesaikan dengan melibatkan pelaku, korban, keluarga pelaku/korban, dan pihak lain yang terkait untuk bersama-sama mencari penyelesaian yang adil dengan menekankan pada pemulihan kembali kekeadaan semula, dan bukan lebih menekankan pada pembalasan. Sedangkan diversi yang dalam hal lain pemberian wewenang bagi pihak penegak hukum terhadap anak setelah dengan pertimbangan mengenai kelayakan dalam penjatuhan hukuman yang pantas diberikan pada anak tersebut, maka penegak hukum akan mengambil tindakan-tindakan atau kebijakan yang dalam menangani atau menyelesaikan masalah pelanggar anak dengan tidak mengambil jalan formal, antara lain menghentikan dan atau meneruskan dari proses peradilan pidana atau mengembalikan/menyerahkan pada masyarakat dan bentukbentuk kegiatan pelayanan sosial lainnya, seperti penyerahan kepada orang tua/ wali, pembinaan sosial, pemberian peringatan/nasihat/konseling, pengenaan denda ataupun memberi ganti rugi kepada korban. Atas hal-hal yang berkaitan tersebut dengan diberlakukannya diversi, maka penuntutan maupun pemeriksaan perkara di pengadilan dapat dihentikan dan anak tidak menjalankan putusan pidana.

Ratio decidendi putusan hakim dalam perkara anak yang melakukan pemerkosaan terhadap anak terkait dengan Putusan Perkara Nomor 206/Pid. Anak/2011/PN.SBY dan Putusan Nomor 113/Pid.Anak/2012/PN.SBY, berdasarkan Pasal 81 Undang-Undang Nomor 23 Tahun 2014 tentang Perlindungan Anak jo 
Pasal 26 Ayat 1 Undang-Undang Nomor 3 Tahun 1997 Tentang Peradilan Anak., dengan ancaman hukuman pidana penjara paling singkat 5 (lima) tahun dan paling lama 15 (lima belas) tahun dan denda paling banyak Rp. 5.000.000.000,- (lima miliar rupiah). Dikarenakan terdakwa masih berusia dibawah 18 tahun dan berstatus sebagai anak maka ancaman hukumannya adalah $1 / 2$ (setengah) dari ancaman hukuman pokok. Berdasarkan Putusan Perkara Nomor 206/Pid.Anak/2011/ PN.SBY, yang menjatuhkan Pidana penjara selama 1 (satu) tahun 6 (enam) bulan dan denda sebesar Rp. 60.000.000.- (enam puluh juta rupiah) dengan ketentuan apabila terdakwa tidak membayarkan pidana denda maka diganti dengan pidana kurungan selama 1 (satu) bulan, dan Putusan Nomor 113/Pid.Anak/2012/PN.SBY yang menjatuhkan Pidana penjara selama 2 (dua) tahun dan denda sebesar Rp. 60.000.000.- (enam puluh juta rupiah) dengan ketentuan apabila terdakwa tidak membayarkan pidana denda maka diganti dengan pidana kurungan selama 3 (tiga) bulan. Putusan tersebut ditinjau dari filosofi pemidanaan anak tidak sesuai dengan kepentingan anak, mengingat anak masih perlu pertimbangan khusus, dimana secara fisik maupun psikis masih memerlukan perlindungan yang berpengaruh terhadap pertumbuhan anak tersebut kedepannya.

\section{Daftar Bacaan}

\section{Buku}

Konvensi tentang Hak-Hak Anak (Convention on the Roghts of the Child), Resolusi No 109 tahun 1990.

Supena, Hadi, Kriminalisasi Anak, PT Gramedia Pustaka Utama, Jakarta, 2010.

\section{Website}

http://www.Fianhar.com/2014/10/Kedudukan-anak-dalam-kejahatan.html, diakses pada tanggal 18 Maret 2017.

http://www.Huraerah/Repositary.usu.ac.id, diakses pada tanggal 8 Agustus 2017.

https://www.mahkamahagung.go.id/id/artikel/2613/keadilan-restoratif-sebagaitujuan-pelaksanaan-diversi-pada-sistem-peradilan-pidana-anak, diakses pada tanggal 06 Juni 2017

HOW TO CITE: Astrid Ayu Pravitria, ‘Anak yang Berkonflik dengan Hukum yang Melakukan Pemerkosaan Terhadap Anak’ (2018) Vol. 